\title{
Avanços metodológicos da microscopia na avaliação de alimentos
}

\author{
Beatriz Lempp ${ }^{1}$
}

1 - Universidade Federal da Grande Dourados. blempp@ufgd.edu.br

RESUMO - O aperfeiçoamento nos últimos anos das lentes de aumento e dos microscópios, bem como o desenvolvimento de técnicas de preparação de amostras, disponibilizou excelentes ferramentas para pesquisas nas diversas áreas da ciência. As avaliações ao microscópio, eletrônico ou óptico, de alimentos utilizados para ruminantes, têm auxiliado na compreensão da relação causa/efeito no desempenho animal. Destacam-se os avanços obtidos no conhecimento do modo de ação dos microrganismos do rúmen nos substratos, principalmente das bactérias partículoassociadas. Avanços também foram obtidos no entendimento dos fatores que afetam a degradabilidade da matéria seca de forrageiras, especialmente das espécies $\mathrm{C}_{3}$, mas estes avanços também contribuem para o conhecimento das $\mathrm{C}_{4}$. Os resultados destes estudos permitiram o estabelecimento de várias linhas de pesquisa, possibilitando discriminar-se nas fases iniciais de seleção de gramíneas e leguminosas, aquelas que apresentam maior potencial qualitativo. Destacam-se também os estudos que estão sendo realizados para elevação da degradabilidade do colmo de milho e do caule da alfafa, bem como, aqueles para identificar-se como o tratamento de subprodutos agrícolas pode elevar sua qualidade, e se verificar o efeito de inoculantes, tais como enzimas exógenas, na taxa de degradação da matéria seca. Além de se verificar o efeito do tanino, especialmente em leguminosas, na digestibilidade, o que pode no futuro possibilitar a utilização de aditivos que minimizem ou anulem seus efeitos deletérios no consumo de forragem. Com relação aos grãos de cereais, pode-se verificar a influência do genótipo na degradação. Os resultados obtidos até então, fornecem a base para a manipulação genética de alimentos utilizados por ruminantes, o que provavelmente será objeto de pesquisa nas próximas décadas.

Palavras chaves: alfafa, gramíneas, milho, tanino

\section{Methodological advances of microscopy in food-stuff evaluation}

\begin{abstract}
The perfecting in the last years of augmentation lenses and that of the microscopes, as well as the development of samples preparation techniques, provided excellent tools in the several science areas. The evaluations at the microscope, electron or optical, of edible products utilized for ruminants, has helped in the cause/effect relationship understanding in animal performance. Of paramount importance are the advances obtained in the action mode of rumen microorganisms in the substrates knowledge, mainly of the particle-associated bacteria. Advances were also achieved in the knowledge of factors that affect the forage dry matter degradability, especially of the $\mathrm{C}_{3}$ species, but these advances also contribute to the knowledge of the $\mathrm{C}_{4}$. These studies results allowed the establishment of several research lines, creating the possibility of discrimination in the early stages of grasses and legumes selection, those which present the greatest qualitative potential. There is especial merit also in the studies to increase the corn and alfalfa stalk degradability, as well as those to identify how the agricultural byproducts treatment can increase its quality, and to verify the effect of inoculants, such as exogenous enzymes, in the dry matter degradability rate. Besides the verification of the tannin effect, especially in legumes, into the digestibility, which may in the future to foster the utilization of additives that can minimize or prevent their harmful effects on forage consumption. With relation to cereal grains, it may be verified the genotype influence on degradability. The results achieved up to now, give the base for the genetic manipulation of feed stuff utilized by ruminants, which probably will be object of research in the next decades.
\end{abstract}

Key Words: alfalfa, corn, grasses, tannins 


\section{Introdução}

O aperfeiçoamento nos últimos anos das lentes de aumento e dos microscópios, bem como o desenvolvimento de técnicas de preparação de amostras, foram praticamente as bases para o progresso da ciência, principalmente na área biológica. Atualmente, a utilização da microscopia eletrônica de varredura (MEV) e de transmissão (MET), constituem excelentes ferramentas disponíveis para pesquisas nas diversas áreas da ciência. Embora a MEV e MET não substituam o microscópio óptico, cada uma tem sua finalidade, dependendo do campo de aplicação.

A MEV tem sido utilizada para estabelecer uma base entre a parede celular e a digestibilidade de forragens, assim como de grãos, pois possibilita a observação e registro da imagem tridimensional. A MET permite verificar-se as inter-relações específicas entre as membranas de células de vegetais, os microrganismos e a forma em que é degradada a forragem ou grãos, visto apresentar alto poder de resolução. O microscópio óptico permite verificar-se os espécimes vivos e amostras nos quais não se necessita de alta amplificação, tais como estruturas anatômicas de tecidos vegetais.

Os trabalhos pioneiros realizados por Robert E. Hungate sobre microbiologia de rúmen a partir de 1935, isolando e identificando bactérias (Bacteroides, agora Fibrobacter succinogenes e Ruminococcus flavefaciens, dentre outras), resultaram em vários artigos e no livro The rumen and its microbes, publicações estas que formaram a base para os avanços tecnológicos na área de nutrição de ruminantes. Nestes trabalhos, a microscopia foi uma ferramenta extremamente importante, permitindo o estudo do ecossistema ruminal. Avanços também ocorreram na avaliação de alimentos para ruminantes com a utilização da microscopia, permitindo elucidar-se em vários substratos a relação causa/efeito no processo de degradação.

A seguir vamos demonstrar como a microscopia tem auxiliado na avaliação de alimentos para ruminantes, ressaltando-se gramíneas tropicais, milho para ensilagem, tratamento de resíduos agrícolas, leguminosas (alfafa), forragens com tanino e milho grão, bem como quais as implicações da utilização desta ferramenta para as pesquisas futuras.

\section{Gramíneas tropicais}

Os estudos anatômicos com forrageiras visando verificar-se o efeito da anatomia na digestibilidade, iniciaram-se a partir de 1970 (Hanna et al., 1973 e Akin et al., 1973). Estes estudos complementam as informações sobre os fatores que interferem na qualidade das forrageiras, visto que nem sempre a análise química e a digestibilidade explicam todas as variações no consumo das forrageiras. Akin e Hartley (1992), consideraram que no preparo das amostras misturam-se vários tecidos que apresentam digestibilidade distinta. A digestibilidade da parede celular de gramíneas pode variar de 30 a $60 \%$, ao passo que a dos diferentes tecidos das lâminas foliares, de 0 a $100 \%$ (Wilson, 1993).

Nas lâminas foliares de gramíneas, as células que apresentam alta digestibilidade são as de mesofilo (MES) e de floema (FLO), as de epiderme, abaxial (EPIaba) e adaxial (EPIada), e de bainha parenquimática dos feixes (BPF), são parcialmente digeridas. Já as de esclerênquima (ESC) e xilema (XIL), são indigestíveis. A maior qualidade geralmente observada nas lâminas foliares de gramíneas $\mathrm{C}_{3}$ em relação às $\mathrm{C}_{4}$, é também atribuída às diferenças na proporção de tecidos. As espécies $\mathrm{C}_{4}$ apresentam menor proporção de MES, células da BPF bem desenvolvidas (Black, 1971), alta freqüência de feixes vasculares (Wilson et al., 1983) e um denso acondicionamento dos tecidos (Hanna et al., 1973), em relação às $C_{3}$.

A proporção de células de MES nas lâminas foliares de $\mathrm{C}_{4}$ é variável entre as espécies e cultivares, porém, é geralmente inferior a $45 \%$. O desaparecimento destas células no rúmen é elevado, apresentando digestão completa normalmente após 12 a 24 horas de incubação (Akin et al., 1983; Magai et al., 1994). Na Figura 1, podese observar o desaparecimento total das células de MES após 24 h de incubação in situ em lâminas foliares de duas espécies de Brachiaria, que reconhecidamente apresentam qualidade distinta, sendo maior para as lâminas foliares de $B$. ruziziensis em relação à $B$. humidicola.

As células de FLO, localizadas no tecido vascular, são rapidamente digeridas nas espécies $\mathrm{C}_{3}$, nas quais representam maior proporção do que nas $\mathrm{C}_{4}$. Já nas $\mathrm{C}_{4}$, podem apresentar compostos 
fenólicos que interferem negativamente na degradabilidade, mas por estas células representarem em torno de $2 \%$ (seção transversal), não comprometem a digestibilidade da forragem.

O tecido epidérmico apresenta parede espessa, com uma camada de cutícula em torno de $0,5 \mathrm{~mm}$, sendo esta influenciada pelo ambiente (Mauseth, 1988). Harbers et al. (1981), citaram que a cutícula contém sílica, conferindo rigidez e impedindo a digestão, bem como que a cutícula per se pode ser um inibidor estrutural da digestão. Prychid et al. (2003), relataram que a sílica pode estar localizada na epiderme acima das células de ESC na estrutura girder, sendo a epiderme stegmata. Wilson et al. (1989), observaram arranjo de células de ESC entre as células da EPI e as da BPF, formando a estrutura girder, sendo girder I quando com a EPI abaxial e adaxial, e girder T quando na EPI adaxial ou abaxial (Figura 2). A estrutura girder pode ter efeito direto na resistência que as lâminas oferecem à digestão, visto interferir na taxa de degradação dos tecidos, como ficou demonstrado por Wilson et al. (1989), Flores et al. (1993), Lempp (1997) e Paciullo et al. (2002).

A estrutura das células de EPI nas gramíneas tropicais, localização de sílica, espessura da cutícula e sinuosidade das células, necessitam ser melhor avaliadas, para se verificar o efeito no desem- penho animal. Lempp et al. (2005), observaram ao microscópio óptico que nas lâminas de $B$. brizantha $\mathrm{B} 4$ ocorreram menor desaparecimento de tecidos (24h, in vitro) em relação à B9 (Figura $3 \mathrm{a}$ e b). Sendo que B4 apresentou EPI stegmata (Figura 3c e d), além de alta freqüência de estrutura girder, em relação à B9. Diferenças entre estes dois genótipos quanto à composição química, incluindo teor de sílica, e digestibilidade in vitro da matéria orgânica, não foram observadas por Torres (2002).

Por outro lado, a epiderme exerce papel importante ao conferir proteção à planta, como também a cutícula e a sílica, visto diminuírem a perda de água por evaporação e serem um mecanismo de defesa contra patógenos, bactérias e fungos (Jenks et al., 1994).

As técnicas utilizadas no preparo das amostras para as observações ao microscópio óptico da seção transversal (Figuras 1, 2 e $3 \mathrm{a}$ e b) estão descritas por Daykin \& Hussey (1985) e Hagquist (1974). Já para se isolar a EPI (Figura 3c e d), utilizou-se solução de Jeffery (Johansen, 1940) e a coloração quádrupla triarca dos tecidos (Hagquist, 1974). Theunissen (1989), também apresenta um método para o estudo de epiderme de gramíneas.

Pode-se observar nas Figuras 1 e 3 (a e b) que a maior diferença no desaparecimento de tecidos entre as lâminas de Brachiaria spp. ocorreu nas

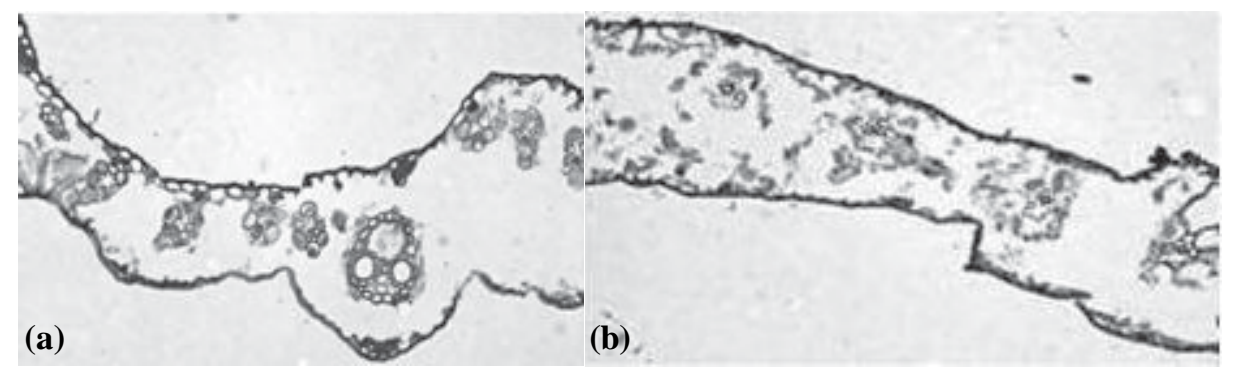

Figura 1 - Seção transversal de resíduo da incubação in vitro (24 h) de lâmina foliar de Brachiaria ruziziensis cv. Kennedy (a) e B. humidicola cv.Tully (b), \% $10 \mu \mathrm{m}$.
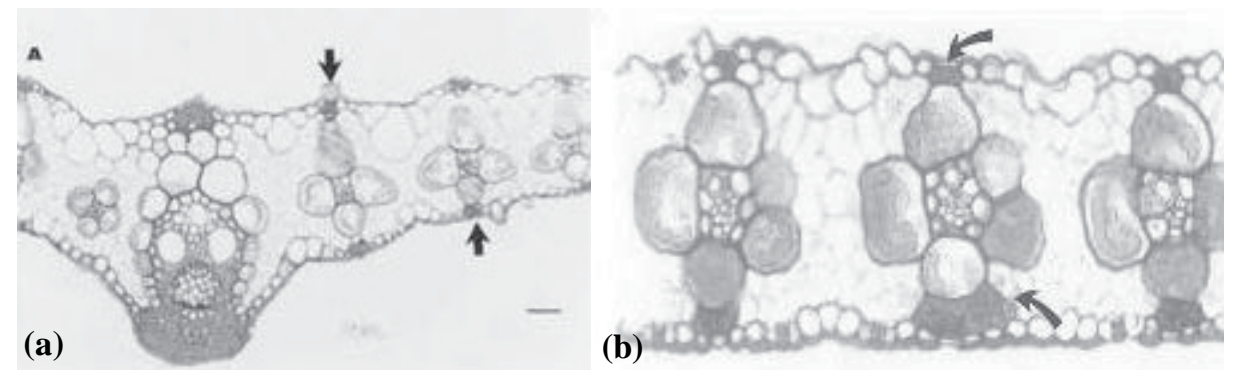

Figura 2 - Seção transversal de fragmentos de lâminas da extrusa de Panicum maximum. (a). cv Aruana, $\rightarrow$ estrutura girder T $(-30,0 \mu \mathrm{m})$. (b). cv. Vencedor, $\rightarrow$ girder I $(-20,0 \mu \mathrm{m})$.Fonte: Lempp, 1997. 
células da BPF, o que pode explicar muitas das diferenças obtidas no desempenho animal entre as gramíneas, visto que as células da BPF apresentam alto teor de proteína e amido (Wilson, 1993), e representam geralmente de 20 a $35 \%$ da seção transversal.

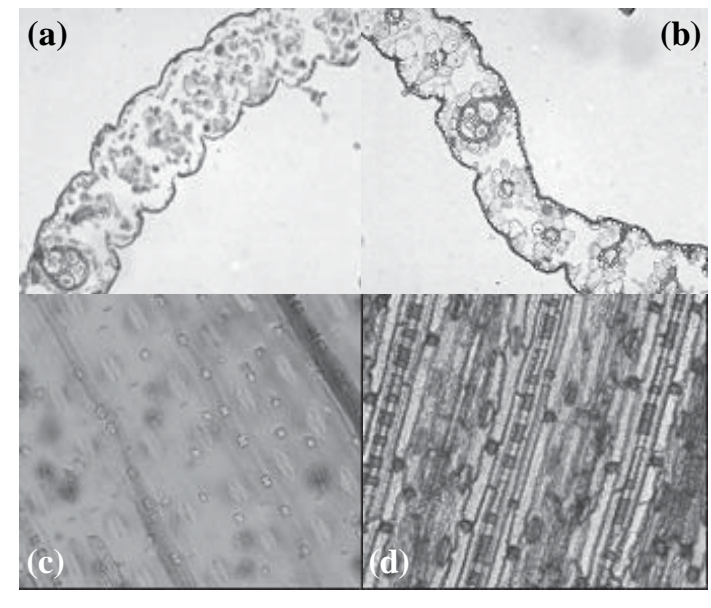

Figure 3 - Seção transversal de lâminas foliares de Brachiaria brizantha acessos B9 (a) e B4 (b) incubados in vitro por $24 \mathrm{~h}$. Epiderme abaxial (c. B9 e d. B4) (-20 $\mu$ m).Fonte: Lempp et al., 2005.

As observações ao microscópio óptico, MEV e MET, permitem se verificar que existem diferenças nas células de BPF em $P$. maximum. Wilson \& Hattersley (1983), observaram por meio da MET a presença de suberina na lamela média de BPF em Panicum spp. (PCK e NADP-ME), sendo considerado fator negativo na degradabilidade destas células. E Lempp (1997), verificou ao MEV que a parede celular da BPF de $P$. maximum cv. Vencedor apresentou-se mais rígida em relação à de cv. Aruana (Figura 4), sem contudo verificar diferenças na composição química entre as cultivares. Já ao microscópio óptico, ocorreu maior reação com safranina-O, indicativo de lignina, na parede celular de BPF da cv. Vencedor em relação à cv. Aruana.

A parede celular da BPF de cultivares de Brachiaria spp. também apresentou espessura e intensidade de coloração com safranina-O diferentes entre si, sendo resultados parciais obtidos com avaliações dos genótipos do programa de desenvolvimento de novas cultivares de Brachiaria spp., Embrapa Gado de Corte (Valle \& Ceolin, comunicação pessoal). Por outro lado,

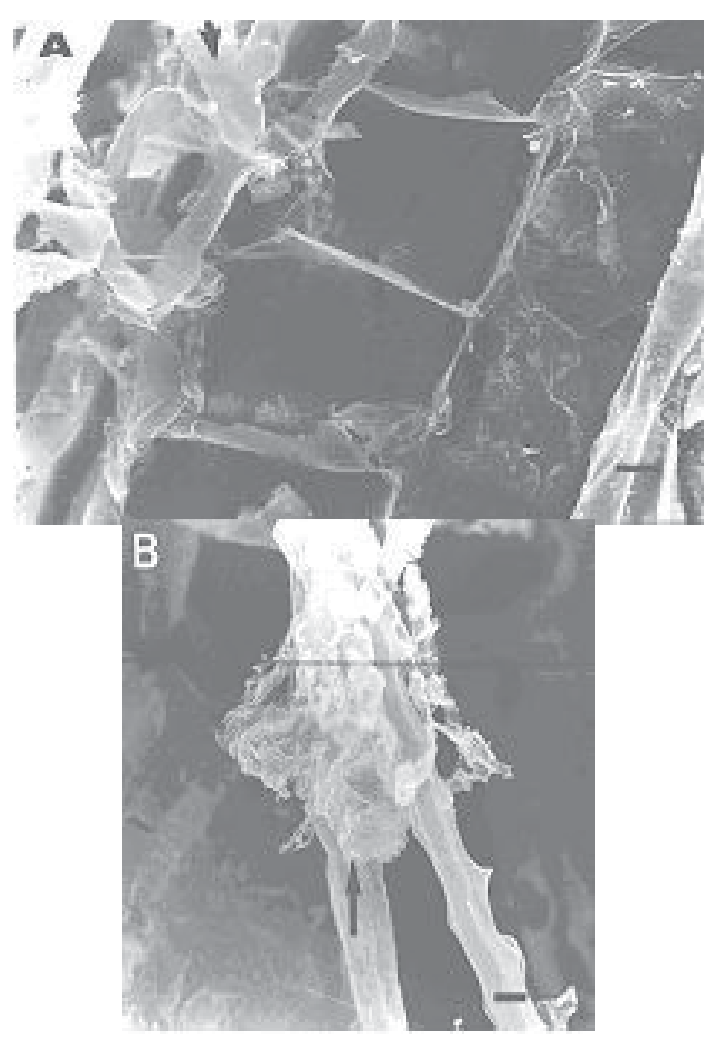

Figura 4 - Elétrons-micrografia de varredura do resíduo da digestão de fragmentos das lâminas da extrusa de Panicum maximum (72 h, in vitro). (A). cv Vencedor (. - 4,2 $\mu \mathrm{m})$, (B). cv. Aruana $(-9,2 \mu \mathrm{m})$. Fonte: Lempp, 1997.

as células da BPF conferem resistência a insetos, sendo considerado mecanismo de escape que confere resistência ao pastejo (Briske, 1996).

Estudos são necessários para isolamento das células de BPF e verificação do teor de lignina e composição da hemicelulose da parede celular, porém, devido à alta freqüência de estrutura girder nas gramíneas tropicias, têm ocorrido contaminação com ESC. Isto pode ser verificado por meio da microscopia óptica, o que tem invalidado os resultados de composição química. Em gramíneas $\mathrm{C}_{3}$, já existem relatos de isolamento de tecidos e posterior à análise química, i. e., Grabber \& Jung (1991).

As células de ESC apresentam a parede celular muito espessa, sendo indigestível. Porém, Moghaddam \& Wilman (1998) e Vincent (1991), citaram a importância destas células para suportar o crescimento das lâminas foliares eretas, juntamente com as de xilema, principalmente em ambientes quentes e secos. Provavelmente, na degradabilidade de lâminas, a localização de ESC seja mais importante do que a proporção (seção transversal), a exemplo da estrutura girder. 
As gramíneas também apresentam diferenças quanto à degradabilidade do colmo, o que será discutido a seguir (milho para ensilagem). O estudo da anatomia de lâminas foliares e de colmo, por meio da microscopia, também pode auxiliar na discriminação de genótipos mais promissores qualitativamente. No Brasil há uma premente necessidade de diversificar as pastagens de gramíneas, elevando-se a variabilidade genética daquelas utilizadas na implantação de pastagens, por meio de lançamento de novas cultivares comerciais. Neste sentido, podem-se adotar procedimentos microscópicos nos ensaios que visam o desenvol-vimento de novas cultivares, por meio de seleção ou cruzamentos, para auxiliar na escolha de cultivares e ou genitores.

\section{Milho para ensilagem}

A produção de forragem no Brasil, que se concentra no verão, faz com que os pecuaristas se preocupem com a suplementação animal, com silagem ou feno, no período da seca. Para a confecção de silagem se destaca o milho, devido ao acúmulo de massa e à composição química das plantas que favorece o processo de fermentação. O valor nutritivo da silagem de milho tem sido relatado como uma função da proporção de grãos na massa, dentre outros fatores, porém a degradabilidade da parede celular do colmo da planta também merece destaque.

(A)

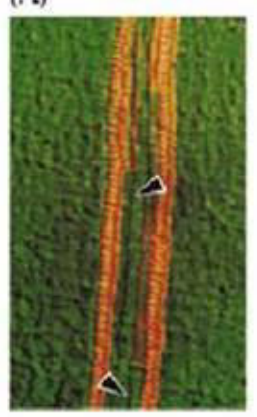

(B)

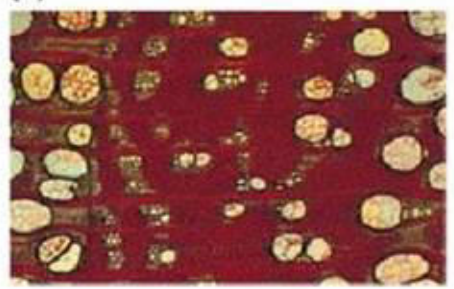

(D)

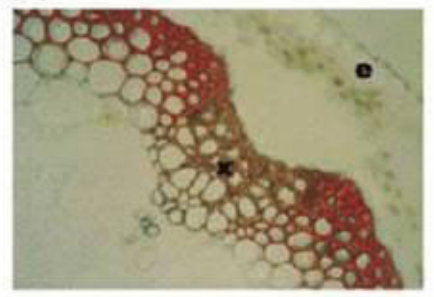

No Brasil, vários genótipos de milho e sorgo estão disponíveis para seleção e melhoramento, porém, segundo Jung et al. (1998), os fatores que limitam a degradação da parede celular do entrenó de colmo destas plantas não são bem entendidos. Sabe-se, entretanto, que dos componentes associados à parede celular, a lignina é a entidade química que reconhecidamente limita a digestão dos polissacarídeos no rúmen (Jung \& Deetz, 1993). A biossíntese da lignina é controlada individualmente na célula, podendo ocorrer diferenças quanto ao tipo deste polímero: $p$-hidroxifenil, guaiacil $(G)$ e ou siringil (S), em função do genótipo, do tecido e do compartimento subcelular (Terashima et al., 1993), além de ser também influenciada pelas maturidade e temperatura (Morrison et al., 1998).

A utilização de testes histoquímicos em material vegetal permite identificação dos tecidos lignificados e também o tipo de lignina, G ou $\mathrm{S}$, com o reagente de Mäule (Nakano \& Meshitsuka, 1992), Figura 5. A utilização de astra-blue ou safranina permite verificar-se se o material vegetal apresenta ou não lignina (Srebotnik \& Messner, 1994). O astra-blue apresenta afinidade com a celulose e é incorporado dentro das fibras somente na ausência de lignina, ao passo que a safranina reage com a lignina independente da presença de celulose (Figura 6).

Portanto, avaliações histológicas de colmo podem permitir a seleção de genótipos de milho ou sorgo com atributos agronômicos desejáveis,
(C)

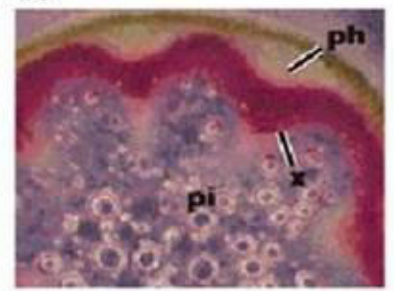

(E)

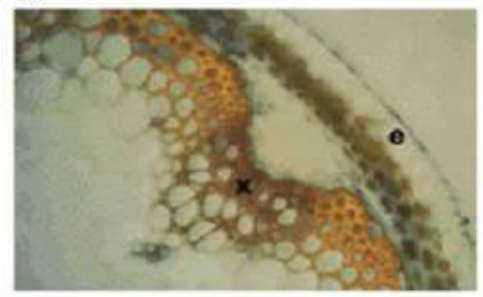

Figura 5 - (A). Tecidos vasculares corados com fuccina ácida $(\rightarrow$ ). (B). Xilema corado com floroglucinol. (C). fibras extraxilemáticas coradas com floroglucionol psis. (D). Reagente de Mäule que reage com lignina siringil - coloração amarela (feito com álcoois sinápil) e com lignina guiacil - coloração amarela (feito com coniferóis). (E). Mutante de Arabidopsis incapaz de sintetizar lignina siringil. ph= córtex, $\mathrm{x}=$ xilema; pi= parenquima medular, e= epiderme. Fonte: Klock (2004). 

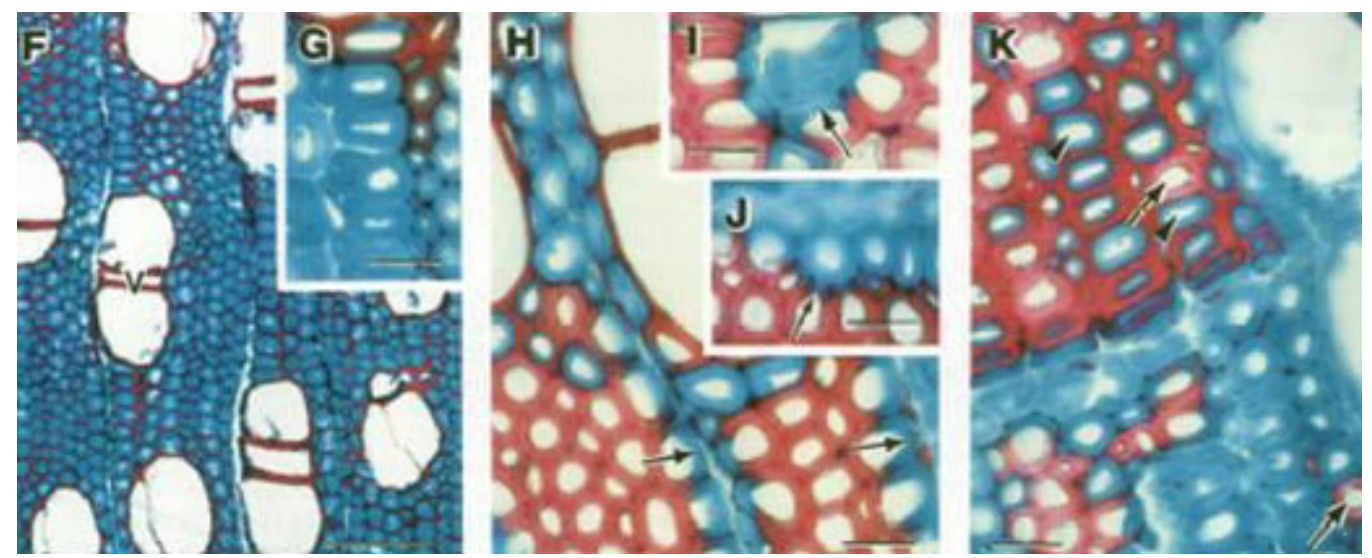

Figura 6 - Reação de celulose na ausência de lignina com astra-blue - coloração azul, e da safranina-O com lignina - coloração vermelha. Fonte: Srebotnik \& Messner, 1994.

mas com características qualitativas desejáveis, como com menor teor de lignina com unidades $\mathrm{S}$. Ralph et al. (1998), indicaram a plasticidade metabólica para a lignificação das plantas, o que permite a manipulação genética. Avaliações de milho transgênico para confecção de silagem já estão sendo divulgadas na literatura, i.e., Jung \& Sheaffer, 2004.

Junkg \& Buxton (1994), ao avaliarem 45 linhas autofecundadas de milho, inclusive brown-midrid, verificaram alto grau de variação genética para a qualidade da parede celular de colmo. Argillier $e t$ al. (2000), citaram a possibilidade de se selecionar híbridos de milho com boa degradabilidade da parede celular e, simultaneamente, alto acúmulo de biomassa. Mèchin et al. (2001), ao avaliarem 100 linhas autofecundadas de milho, verificaram independência genética entre o teor e a digestibilidade de fibra e teor de amido, sendo os dois componentes responsáveis pela digestibilidade da planta.

Por meio da microscopia pode-se avaliar a extensão do desaparecimento dos tecidos dos entrenós e ou lâminas de milho/sorgo. Para este procedimento, incubam-se os fragmentos morfológicos e, transcorridos os tempos pré-fixados, fazse o preparo histológico do resíduo, corte e coloração. Esta avaliação pode permitir a identificação dos genótipos com maior taxa de desaparecimento de tecidos nas fases iniciais da seleção genética.

Jung \& Casler (2006a), observaram que o aumento no teor de parede celular no entrenó de três híbridos de milho foi associado ao espessamento da parede celular secundária na região do córtex. Ainda Jung \& Casler (2006b), ao observarem o resíduo da degradação (24 e 96 h) do entrenó do mesmo material ao microscópio óptico, verificaram que a degradação ocorreu preferencialmente na região medular, ao passo que a do córtex permaneceu intacta após 96 h de incubação (Figura 7).

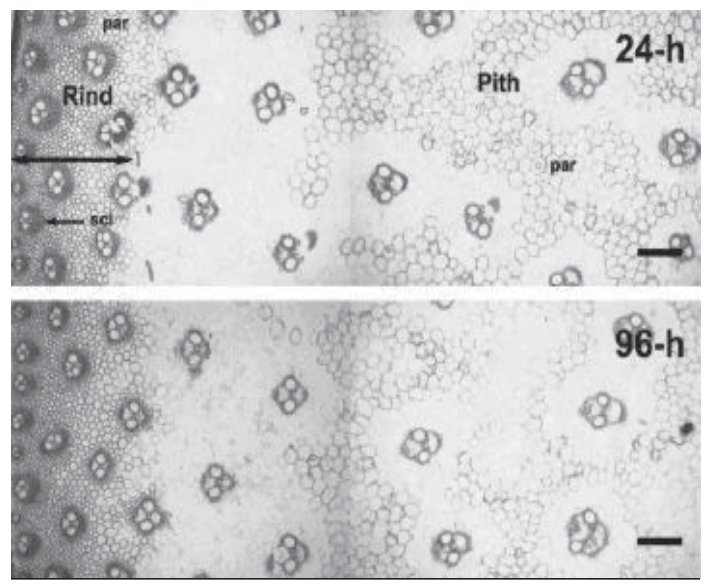

Figura 7 - Micrografia do resíduo da incubação in vitro $(24 \mathrm{e} 96 \mathrm{~h}$ ) do entrenó de milho (híbrido 632 na maturidade fisiológica), $(\mathbf{a})=$ região não degradada (córtex), e (b) = região parcialmente degrada (medular), $\mathrm{scl}=$ esclerênquima, par = parênquima (\% $500 \mu \mathrm{m})$.Fonte: Jung \& Casler (2006b).

A caracterização morfoanatômica do entrenó do colmo de milho e sorgo, dentre outros, permite o conhecimento dos fatores intrínsecos às plantas, que interferem na qualidade da silagem. Os estudos nos tecidos lignificáveis com relação às unidades de lignina, $\mathrm{S}$ ou G, ainda são pouco explorados. Parece-nos que a melhor estratégia para elevar-se o valor nutritivo das silagens (milho ou sorgo, dentre outras, i.e., Pennisetum purpureum) é 
modificando-se a biossíntese de lignina no entrenó, diminuindo-se assim a relação $\mathrm{S}: \mathrm{G}$.

\section{Tratamento químico de alimentos}

O ecossistema microbiano ruminal compreende no mínimo 30 espécies de bactérias predominantes, sendo que as partículo-associadas predominam no rúmen (Craig et al., 1987). Por meio de observações ao MEV realizadas por Miron et al. (1989), Miron \& Bem-Ghedalia, (1992 e 1993), dentre outros, pode-se entender o processo de adesão das bactérias nas partículas de alimentos. Miron et al. (2001), citaram os fatores que afetam a colonização dos microrganismos nas partículas de alimentos. Dentre estes, referiram-se ao substrato, como proteção pela cutícula, área de superfície e capacidade de troca cátion iônica.

Assim, estudos como estes forneceram subsídios para se verificar o efeito de inoculantes ou tratamentos químicos na degradação da parede celular dos substratos. Mas, Krause et al. (2003), sugeriram que o insucesso obtido com a utilização de inoculantes, visto que não melhoraram a digestão da fibra in vivo, refere-se ainda ao entendimento superficial acerca do ecossistema microbiano ruminal.

Martins (2003), verificou o efeito de enzimas fibrolíticas exógenas sobre a degradabilidade in situ do feno de Tifton 85 (Cynodon spp.), aos $30 \mathrm{e}$ aos 90 dias, e do bagaço de cana-de-açúcar. Maior degradação da parede celular em resposta à adição de enzimas foi verificada no bagaço de cana, o que pode ser explicado pela maior concentração de bactérias neste resíduo (Figura 8).

Wang et al. (2006), observaram o efeito do tratamento com $\mathrm{NaOH}$ e $\mathrm{NH}_{4} \mathrm{HCO}_{3}$ no colmo da palha de arroz. $\mathrm{O} \mathrm{NH}_{4} \mathrm{HCO}_{3}$ acelerou a ruptura da camada de cutícula (Figura 9a), mas a epiderme permaneceu intacta após $48 \mathrm{~h}$ de incubação no rúmen. Já o $\mathrm{NaOH}$ dissolveu a camada de cutícula, resultando em degradação da epiderme (Figura 9 b e c).

Da mesma forma, estudos estão sendo conduzidos com o tratamento físico de grãos visando melhorar a eficiência de utilização pelos ruminantes. Morais et al. (2007, não publicado), verificaram que o grão de milho triturado grosso apresentou menor área de superfície em relação ao fino (Figuras 10a e b). E após 48 de degradação in situ, maior indicativo de degradação do amido ocorreu no triturado fino em comparação ao grosso (Figura 10 c e d).
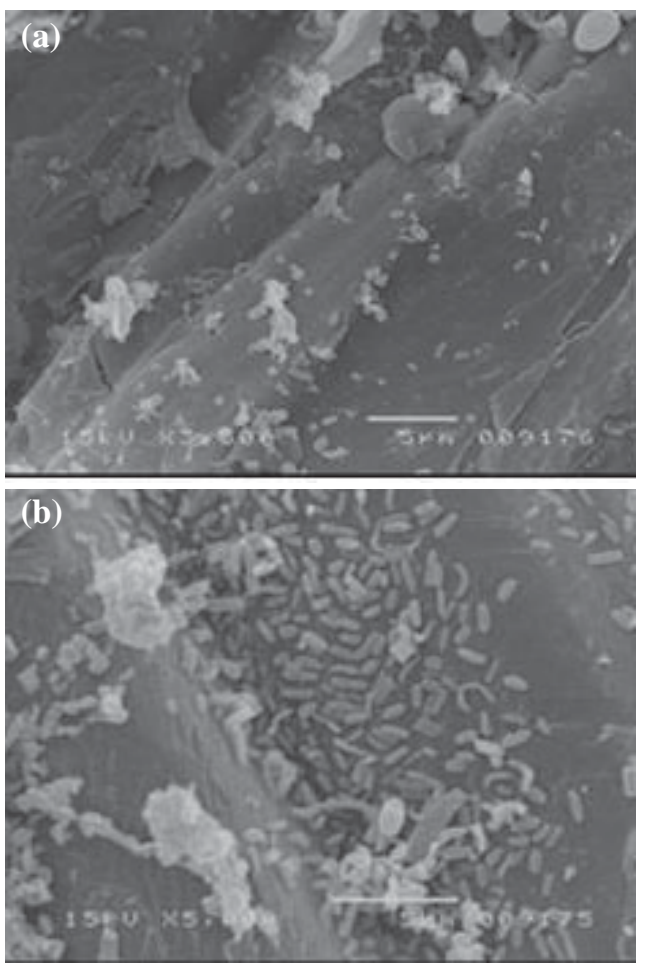

Figura 8 - Elétrons-micrografia de varredura dos resíduos de degradação in situ (48 h) do bagaço de cana-de-açúcar sem (a) e com a adição de enzimas fibrolíticas (b). Fonte: Martins (2003).

Nos últimos 50 anos, avanços significativos ocorreram no entendimento sobre o processo de digestão da fibra no rúmen, i.e., a importância do nitrogênio para as bactérias fibrolíticas, o que resultou na indicação da suplementação de uréia. No entanto, os estudos têm sido realizados com poucas espécies de bactérias, e muito menos atenção tem sido dispensada para protozoários e fungos. Mas, por outro lado, avanços também ocorreram na manipulação genética de bactérias ruminais, o que tem sido objeto de estudo por Teather et al. (1997). Neste sentido, a microscopia pode auxiliar no entendimento das interações entre microrganismos. Considera-se aqui, que os estudos são realizados com culturas de bactérias puras, o que pode não representar as condições in vivo.

\section{Leguminosas (alfafa)}

Nas espécies C3, foram realizados progressos com a remoção ou minimização dos fatores

(ㄷ 2007 Sociedade Brasileira de Zootecnia 

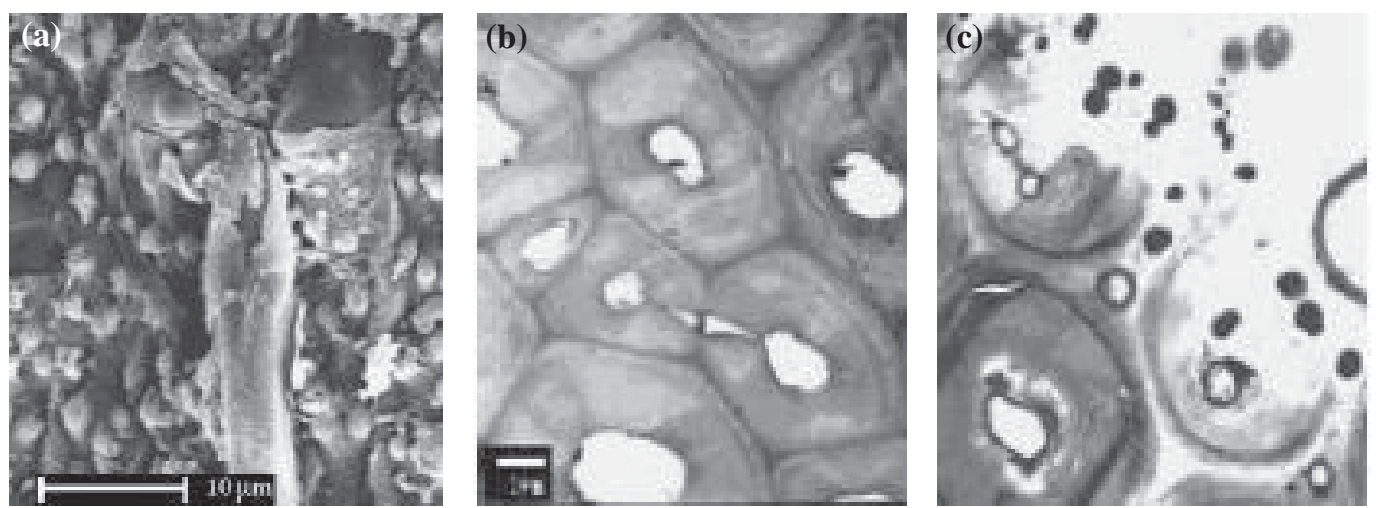

Figura 9 - (a). Elétrons-micrografia de varredura de epiderme (EPI) do colmo de arroz tratado com $\mathrm{NH}_{4} \mathrm{CO}_{3}$ (cutícula danificada). Elétron-micrografias de transmissão - (b). EPI de colmo de arroz sem tratamento $(-1 \mu \mathrm{m})$ e (c). tratado com $\mathrm{NaOH}$ (dissolução da cutícula e degradabilidade da EPI) (\% $1 \mu \mathrm{m})$. Fonte: Wang et al. (2006).

antiqualitativos encontrados em algumas forrageiras, tais como Trifolium subterraneum e Festuca arundinacea (Casler \& Vogel, 1999). Nos dias atuais, se concentram esforços em melhorar a degradabilidade do caule da alfafa (Medicago sativa L.), visto que a digestibilidade das folhas das leguminosas não se altera significativamente com a maturidade. Assim, o teor de lignina do caule é que afeta negativamente a degradabilidade da alfafa (Galyean \& Goetsch, 1993).

Guo et al. (2001), verificaram que as linhas transgênicas de alfafa (AC310 e ACC315) apresentaram maior degradabilidade $(\mathrm{p}<0,025)$ de forragem em relação às linhas controle, após $36 \mathrm{e}$ 72 horas de incubação in situ. E, por meio de coloração histoquímica, observaram que no caule de AC310 ocorreram perdas de unidades S (menor coloração com reagente de Mäule) e na ACC305 perda de lignina (menor reação com safranina $\mathrm{O}$ ) em relação ao controle (Figura 11. 1). As técnicas de coloração utilizadas foram descritas por Nakano \& Meshitsuka (1992), reagente de Mäule, e Srebotnik \& Messener (1994), safranina O.

As estratégias para elevar-se a qualidade da alfafa por meio da biologia molecular são aquelas que visam a modificação da biossíntese da lignina e o aumento do teor de pectina na parede celular. Por outro lado, transformações genéticas para alterar a biossíntese da lignina podem resultar em plantas agronomicamente inviáveis. Higuchi (1990), ressaltou a diversidade de funções que a lignina exerce na planta, dentre estas mecanismo de suporte, transporte de água e resistência a doenças.

Para que ocorra sucesso na alteração da biossíntese da lignina no caule da alfafa, deve-se entender a estrutura e a degradabilidade da parede celular dos diferentes tecidos. Neste sentido, os estudos de Engels \& Jung (1998) e Jung \& Engels (2002), em que ambos recorreram às avaliações do caule ao microscópio, forneceram importantes informações quanto à influência da anatomia do caule na degradabilidade da alfafa.

Engles \& Jung (1998), estudaram três genótipos de alfafa que diferiram quanto à digestibilidade do caule in vitro. Nestes materiais, por meio de avaliações histológicas, descreveram o efeito da maturidade nos tecidos do caule. Para verificarem a lignificação da parede celular, utilizaram floroglucinol (0,5 g em $\mathrm{HCl} 15 \%)$, o
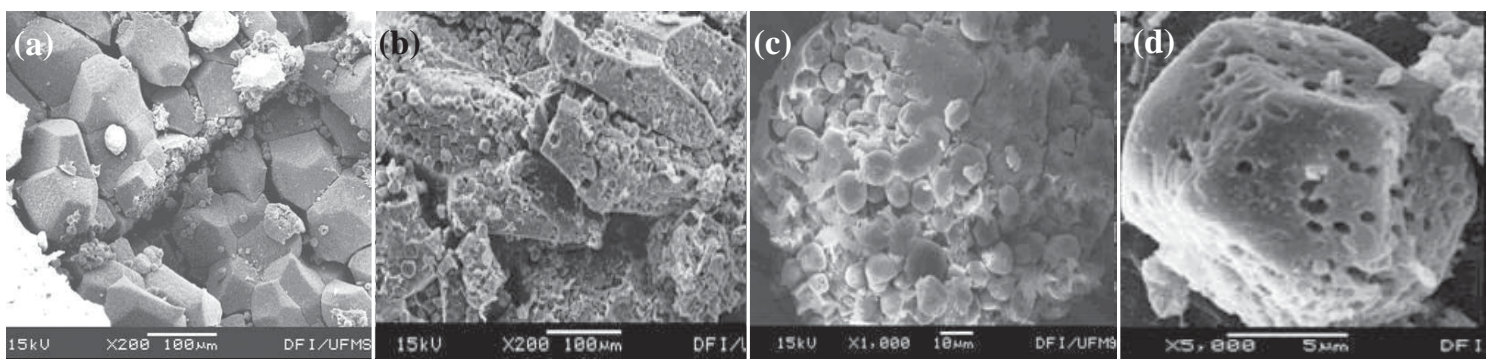

Figura 10 - Elétrons-micrografia de varredura de grão de milho triturado grosso (a) e fino (b) e, incubados por 48 h no rúmen (c - triturado grosso e d - fino). Fonte: Morais et al. (2007).

() 2007 Sociedade Brasileira de Zootecnia 

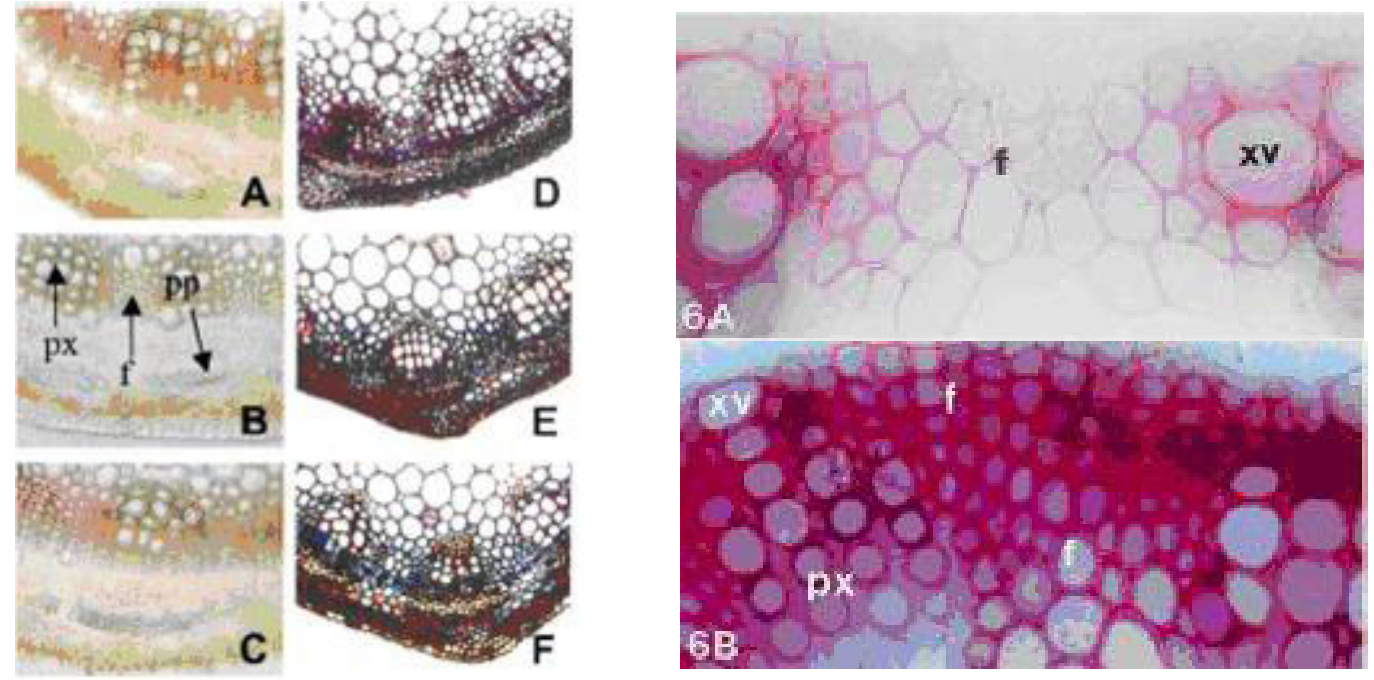

Figura 11 - 1. Seção transversal de caule de alfafa (sexto entrenó) após coloração com reagente de Mäule (1A a 1C), e astra blue e safranina O (1D a 1F). Controle - linha 48 (1A e 1D), linha AC310 (1B e 1E) e linha ACC305 (1C e 1F). pp= floema primário, px= xilema primário, $\mathrm{f}=$ fibras de xilema (x 15). 2. Seção transversal de caule de alfafa com tecido em desenvolvimento (2A - x 450), e desenvolvido (2B - x 285), com reação positiva com floroglucinol. xv= vasos de xilema. Fontes: 1. Guo et al. (2001), 2. Engles \& Jung (1998).

qual reage com dois grupos presentes na lignina (coniferyladehyde e cinnamaldehyde) (Figura 11 2).

Jung \& Engels (2002), incubaram (in vitro, 48 h) fragmentos de caule de alfafa em diferentes estágios de desenvolvimento. No preparo histológico, utilizaram o floroglucinol e ruthenium red (Jensen, 1962), para verificarem, respectivamente, lignina e pectina nos diferentes tecidos. Os autores concluíram que, para melhorar-se a qualidade da alfafa, dever-se-ia reduzir a quantidade de lignina depositada no xilema. Na Figura 12 , pode-se verificar que, independentemente do estágio de desenvolvimento, o único tecido que permaneceu indegradável foi o xilema, bem como que a alta degradabilidade da pectina deve-se ao fato desta estar presente em tecidos não lignificados.

Os resultados obtidos pelos autores citados anteriormente, dentre outros, forneceram a base para outros estudos, nos quais se procura entender a relação causa/efeito na degradabilidade da forragem, e, como conseqüência, a seleção de genótipos de maior potencial qualitativo. Por exemplo, Tecle et al. (2006), avaliaram cinco populações de alfafa oriundas de cruzamentos para

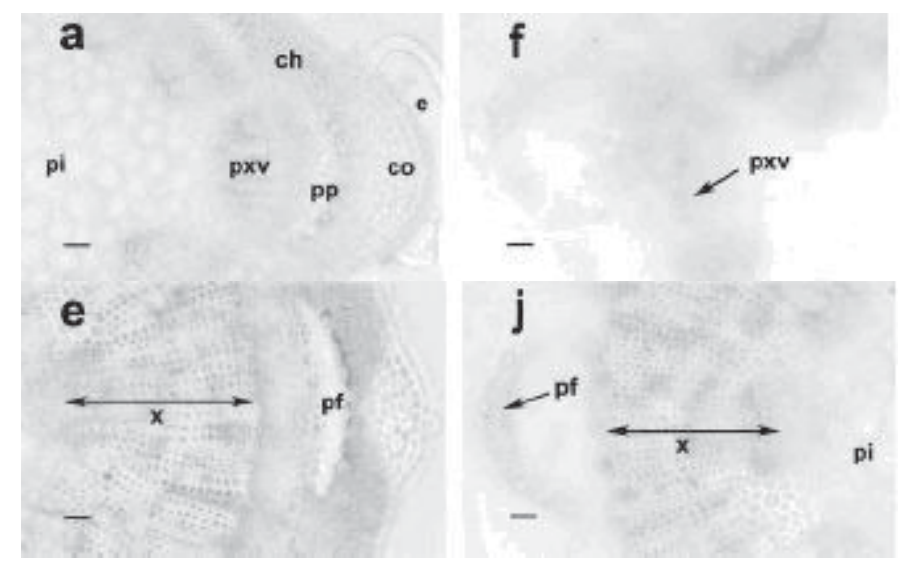

Figura 12 - Seção transversal de caule de alfafa. (a). início do alongamento do sétimo entrenó e (f). resíduo da degradabilidade in vitro (48 h). (e). entrenó desenvolvido e (j). resíduo da degradabilidade in vitro $(48 \mathrm{~h}) . \mathrm{ch}=$ clorênquima, $\mathrm{e}=$ epiderme, $\mathrm{co}=$ colênquima, $\mathrm{pi}=$ parênquima, $\mathrm{pxv}=$ xilema primário, $\mathrm{pp}=$ floema primário, $\mathrm{x}=$ xilema, $\mathrm{pf}=$ fibras de floema. $(-100 \mu \mathrm{m})$. Fonte: Jung \& Engels, 2002. 
resistência às doenças, para selecionar genótipos com maior teor de pectina. Fazendo-se inferências sobre o aumento de pectina, pode-se presumir menor proporção de xilema no caule.

E Jung \& Lamb (2006), avaliaram clones de alfafa e concluíram que os genótipos com alto teor de fibra em detergente neutro rapidamente digestível devem ter entrenós pequenos. Enquanto, os com alto potencial de extensão de digestão da FDN devem possuir entrenós longos.

Sem dúvida, faltam estudos que verifiquem a relação causa/efeito das características da forrageira que conferem maior potencial agronômico em relação ao potencial qualitativo. Estudos estes, que auxiliariam os melhoristas na seleção de germoplasmas, visto correlacionarem características morfológicas com o potencial qualitativo, a exemplo dos resultados obtidos por MacAdam \& Mayland (2003), com Lolium perenne. Recordase que o número de genótipos disponíveis nos bancos de germoplasmas é relativamente elevado, o que impossibilita avaliações qualitativas que realmente os discriminem quanto ao potencial qualitativo. Além de serem poucos os pesquisadores que se dedicam ao melhoramento de forrageiras, em relação aos da área de nutrição de ruminantes, por exemplo.

\section{Forragens com tanino}

Em forragens, $o$ alto teor de tanino condensado (TC) é considerado fator antinutricional para ruminantes, devido causar depressão no consumo e na digestibilidade (Barry \& Duncan, 1984; Barry \& Manley, 1984). Por outro lado, baixo teor de TC pode exercer efeito benéfico na nutrição de ruminantes (Beever et al., 1989).

Scalbert (1991), identificou três mecanismos que explicam a toxidez do tanino para os microrganismos, incluindo a inibição de enzimas extracelulares. O estudo de Jones et al. (1994), ao utilizarem o TC purificado em culturas de bactérias, contribuíram para elucidar o efeito do TC na atividade proteolítica de algumas bactérias ruminais. As observações das culturas de bactérias com e sem TC ao MEV permitiram verificar-se que o TC alterou a morfologia de Butyrivibrio fibrisolvens A38 e de Streptococcus bovis (Figura 13). Possivelmente, segundo os autores, o TC entra nas células dos microrganismos e, após reagir com

๑ 2007 Sociedade Brasileira de Zootecnia os polímeros da membrana, inibem a síntese de alguns compostos da parede celular, incluindo a proteína.

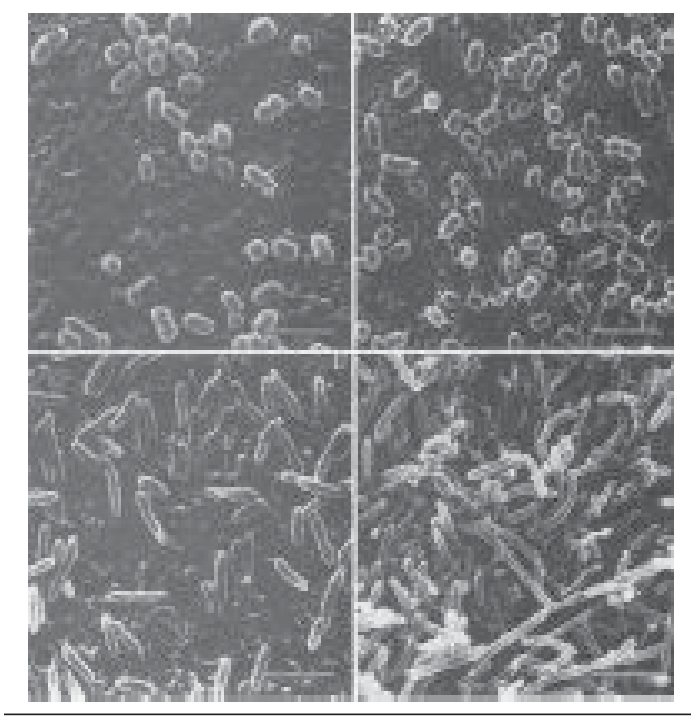

Figura 13 - Elétrons-micrografia de varredura de Butyrivibrio fibrisolvens A38 em cultura sem $(\mathrm{a},-2 \mu \mathrm{m})$ e com (b, $-2 \mu \mathrm{m})$ tanino condensado $\left(100 \mu \mathrm{g} \mathrm{mL}^{-1}\right)$, e de Streptococcus bovis sem (c, $-5 \mu \mathrm{m})$ e com $(\mathrm{d},-5 \mu \mathrm{m})$ tanino condensado $\left(100 \mu \mathrm{g} \mathrm{mL} \mathrm{m}^{-1}\right)$. Fonte: Jones et al. (1994).

O tanino ocorre naturalmente em leguminosas. Nas temperadas têm sido amplamente estudado, ao passo que nas tropicais menos informações são disponíveis, como é o caso de Arachis spp. e de Stylosanthes spp. Isto torna necessário estimar-se o efeito biológico do TC destas forrageiras. A maior limitação para estes estudos relaciona-se aos métodos analíticos. Segundo Reed (1995), nenhum método apresenta resultados satisfatórios para análise quantitativa de tanino em relação ao efeito nutricional. Visto que o TC das leguminosas difere quanto à habilidade para reduzir a atividade das enzimas dos microrganismos (Theodorou et al., 2000).

O tanino não está restrito a algumas famílias de dicotiledôneas, podendo também estar presente em algumas gramíneas (Bernays et al., 1989). Ellis (1990), demonstrou que o tanino é mais freqüente em gramíneas C4 (NADP-ME), particularmente em espécies cujo desenvolvimento ocorre em solos distróficos e deficientes em nitrogênio. $\mathrm{O}$ referido autor observou por meio de estudos anatômicos, a ocorrência de tanino em 39 gêneros e 105 espécies de gramíneas na África do Sul. No Brasil, Meirelles et al. (2005), verificaram maiores teores 
para espécies de Paspalum spp. em relação a $P$. maximum cv. Tanzânia-1 e B. decumbens.

As análises histoquímicas permitem a identificação dos compostos fenólicos em tecidos vegetais. Chesselet et al. (1992), concluíram que os testes histoquímicos podem ser um método rápido para discriminar entre um grande número de genótipos, os que apresentam tanino nos tecidos. Apesar de enfatizarem que os resultados obtidos devem ser interpretados com cuidado, pois, não identificam os compostos fenólicos que têm habilidade de precipitar a proteína e, então, afetar a interação herbívoro-planta.

As observações de seções transversais de lâminas foliares de oito genótipos de Paspalum spp. indicaram diferenças entre estes quanto à presença de compostos fenólicos nas células. Pode-se observar na Figura 14 que ocorreu reação positiva com safranina $\mathrm{O}$ nas células da epiderme. Este resultado é semelhante ao verificado por Ellis (1990), o qual atribuiu a reação positiva à presença de tanino. Para estes estudos vários métodos estão relatados na literatura, dentre estes Johansen (1940), Mace \& Howell (1974), Gahan (1984) e Harbone (1989).

Um estudo mais detalhado com lâminas foliares de Paspalum spp., ou seja, observações ao microscópio do resíduo da degradação de lâminas foliares, permitiriam verificar-se se a reação observada com safranina-O nas células da epiderme interfere no desaparecimento de tecidos. Arachis spp., Paspalum spp. e Stlylosanthes spp. são forrageiras promissoras para determinadas áreas do Brasil, como Acacia aneura para a Austrália, e ambas apresentam tanino. Norton (2000), sugeriu que os estudos relacionados ao tanino podem, no futuro, permitir o desenvol- vimento de inoculantes que modificam ou inibem a ação de taninos no rúmen.

Considerando-se que um dos objetivos dos pesquisadores da área de forragicultura seja melhorar a qualidade da dieta dos animais em pastejo e o suprimento de nitrogênio para as gramíneas tropicais, a seleção de leguminosas com baixo teor de tanino passa a ser uma necessidade. Neste sentido a microscopia pode auxiliar na discriminação de genótipos promissores.

\section{Grão de milho}

A bibliografia apresenta extensa informação quanto aos aspectos relacionados à utilização do amido por ruminantes, quanto às características físicas e químicas dos grãos de cereais que interferem no valor nutritivo (Huntigton, 1997; Owens et al., 1997 e Barneveld 1999, dentre outros). Botanicamente, os grãos de cereais possuem atributos semelhantes, mas poucas características entre duas espécies e variedades são idênticas. Os grânulos de amido são estruturas organizadas, nos quais as moléculas de amilose e amilopectina são ligadas por pontes de hidrogênio. E os teores destes carboidratos influenciam na digestibilidade do amido (Dreher et al., 1984). Grãos de cereais que apresentam maior teor de amilopectina que amilose são mais digestíveis (Kotarski et al., 1992). Por meio da microscopia óptica podem-se identificar os grãos que apresentam maior teor de amilo-se, teste de iodide (Berliyn \& Miksche, 1976).

Este método pode auxiliar tanto na compreensão de resultados obtidos em estudos de digestibilidade quanto na seleção de genótipos de cereais. A proporção de amilose no amido pode

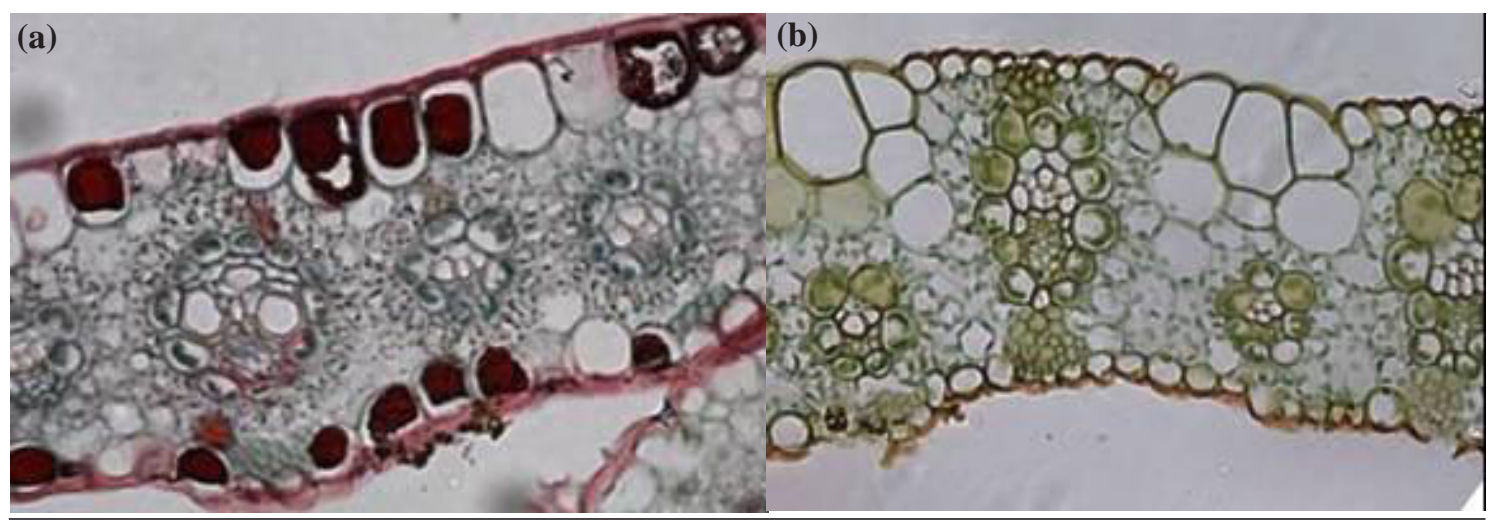

Figura 14 - Seção transversal de lâmina foliar de Paspalum spp. (a. P96 e b. P11). $\rightarrow$ Reação positiva com safranina O nas células da epiderme adaxial e abaxial de P96 $(-10 \mu \mathrm{m})$.

๑ 2007 Sociedade Brasileira de Zootecnia 
variar de 0 a $80 \%$ em função da espécie e de variações genéticas dentro destas. Em cereais normais, a amilose representa de 20 a $30 \%$ do amido, ao passo que nos cerosos o teor é baixo ou inexistente (Rooney \& Pflugfelder, 1986).

Por meio de MEV, pode-se observar que a forma com que os microrganismos degradam os grânulos de amido é diferente, reflexo da composição da parede celular e sua interação com a matriz protéica e da ação dos diferentes microrganismos. McAllister et al. (1990), observaram que $S$. bovis 26, após 4 h de inoculação, colonizaram o grânulo de amido e que após 12 h os grânulos foram removidos, ao passo que a matriz protéica do endosperma permaneceu intacta. (Figura 15 a e b). Já a ação de R. amylophillus no amido foi mais localizada do que a observada com $S$. bovis, sendo que após $24 \mathrm{~h}$ de incubação o interior dos grânulos foi digerido (Figura 15 c). Já na degradação do grânulo de amido de trigo por S. bovis, ocorreu maior erosão da parede em relação à observada no milho (Figura $15 \mathrm{~d}$ ).

Como as bactérias aminolíticas exibem habilidades diferentes para degradar os grãos de cereais, cuja degradação também depende em parte das espécies de cereais, as observações ao MEV do resíduo da digestão podem auxiliar na interpretação dos resultados obtidos com desempenho animal. Cone et al. (1989), verificaram que o grau de degradação do amido de 23 fontes de alimentos variou consideravelmente após seis horas de incubação in vitro, o que foi atribuído às propriedades do amido. Mas, ao se verificar a velocidade de degradação do amido, além das suas propriedades, deve-se considerar também as diferenças na matriz protéica, $\alpha$ ou $\beta$-zeína.

Philippeau \& Michalet-Doreau (1997), ao avaliarem dois híbridos de milho diferentes quanto à textura do endosperma, dentado com 48,1\% de endosperma vítreo e o duro (ou cristalino) com $72,3 \%$, observaram degradabilidade do amido de 61,3 e $40,1 \%$, respectivamente. Estudos anteriores, nos quais se utilizou a microscopia, permitiram elucidar os resultados obtidos pelos autores anteriormente citados. No endosperma vítreo, os grânulos de amido são envolvidos pela matriz protéica, a qual limita a ação de enzimas hidrolíticas. Já no grão farináceo, a matriz protéica é mais descontínua, tornando os grânulos de amido mais acessíveis às bactérias ruminais (Kotarski et al., 1992).

Na Figura 15, pode-se observar que a matriz protéica do endosperma do milho permaneceu intacta após 12 horas de incubação, ao passo que os grânulos de amido foram removidos. De acordo com McAllister et al. (1993), a matriz protéica do endosperma de milho é extremamente resistente à digestão pelos microrganismos do rúmen. Enquanto na cevada outros fatores, tais como os carboidratos da parede celular do endosperma, mais que a matriz protéica, podem limitar o acesso dos microrganismos aos grânulos de amido.

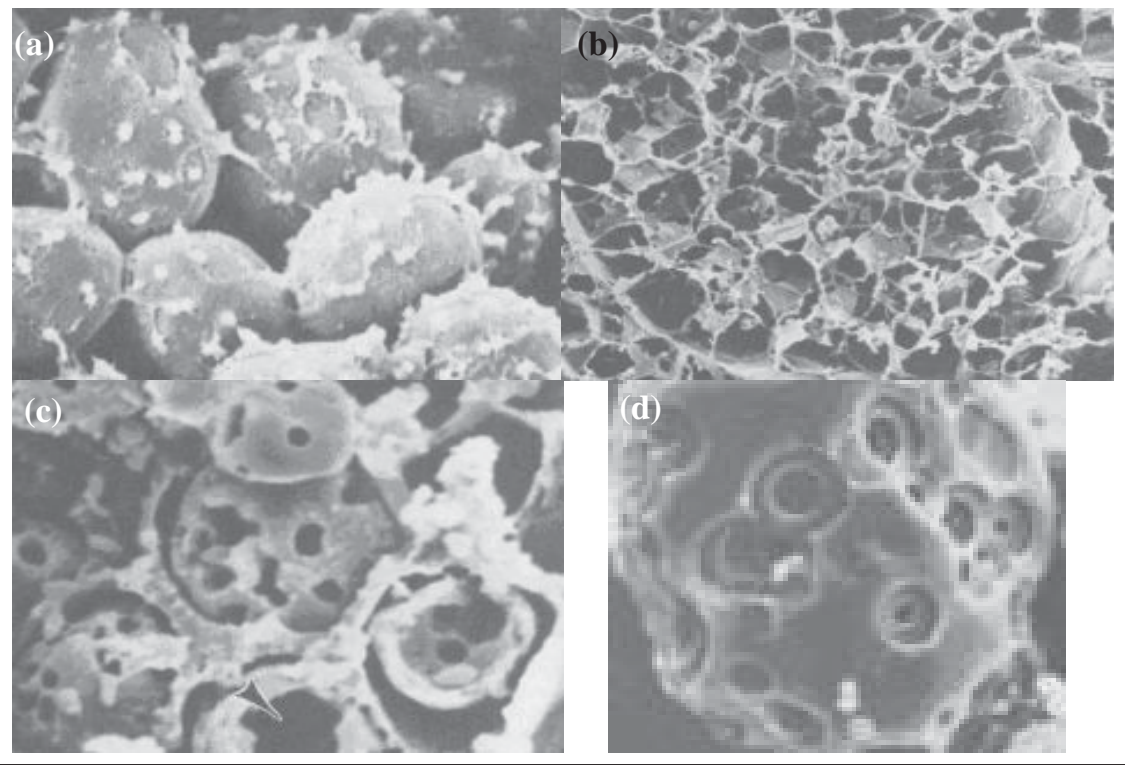

Figura 15 - Életrons-micrografia de varredura de grânulo de amido de milho após 4 h (a) e 12 (b) de incubação com Streptococcus bovis 26, (c) após 24 h de incubação com Ruminococcus amylophillus 70, e (d) grânulo de amido de trigo incubado por 72 h com S. bovis. Fonte: McAllister et al., 1990.

() 2007 Sociedade Brasileira de Zootecnia 
Os grânulos de amido do sorgo também apresentam a matriz protéica resistente à degradação ruminal (McAllister et al., 1994). De acordo com Spicer et al. (1986), a resistência à degradação da matriz protéica do milho e sorgo contribui para a uma menor taxa de passagem do amido para o intestino em bovinos consumindo estes grãos, quando comparado àqueles indivíduos consumindo cevada.

A microscopia pode ser também uma ferramenta útil para se avaliar o efeito do dano mecânico nos grãos pelo processamento. Ao MEV, McAllister et al. (1993), observaram que mesmo após a moagem do milho os grânulos de amido permaneceram na matriz protéica, o que pode em parte, explicar os resultados obtidos entre degradação do amido e características físicas do grão de milho.

A bibliografia (nacional e internacional) é rica em artigos sobre a degradabilidade do amido de milho. No entanto, poucos estudos fazem referência ao genótipo utilizado, se farináceo, dentado, duro ou ceroso, dentre outros. Por outro lado, as tabelas de composição química de alimentos, geralmente utilizadas como base para a confecção de rações, também não fazem distinção entre os diferentes genótipos. Vários lançamentos de variedades de milho têm ocorrido ao longo dos anos, como por exemplo a Embrapa Milho e Sorgo, que lançou recentemente as variedades de milho Quality Protein Maize (QPM), BR451, BR473 e BR2121, todas variedades farináceas com endosperma vítreo.

Neste sentido, as avaliações ao microscópio podem auxiliar no entendimento do processo de degradação ruminal e nas suas respectivas implicações, por dois motivos: o primeiro, baseado em Taylor \& Allen (2005), é o fato de o tipo de endosperma do grão de milho influenciar o local de digestão do amido, o que faz com que se deva considerar este efeito no balanceamento de rações experimentais; já o segundo deve-se ao fato que García-Lara et al. (2004) sugeriram, de que os mecanismos estruturais que conferem resistência ao grão de milho contra insetos no armazenamento deveriam ser considerados em programas de melhoramento. Ou seja, devem-se elevar os teores de ácidos hidroxycinnamic no pericarpo e de compostos fenólicos na camada de aleurona.

\section{Agradecimento}

Aos professores Dr. Antonio Carlos Cubas (Universidade Federal da Grande Dourados) e Dra. Maria da Graça Morais (Universidade Federal de Mato Grosso do Sul) pelas valiosas contribuições na revisão deste trabalho.

\section{Literatura citada}

AKIN, D.E.; AMOS, H.E.; BARTON, F.E. et al. Rumen microbial degradation of grass tissue revealed by scanning electron microscopy. Agronomy Journal, v.65, n.5, p.825828, 1973.

AKIN, D.E.;HARTLEY, R.D. UV absorption microspectrophometry and digestibility of cell types of bermudagrass internodes at different stages of maturity. Journal of Science Food Agricultural, v.59, n.2 p.437-447, 1992.

AKIN, D.E.; WILSON, J.R.; WINDHAM, W.R. Site and rate of tissue digestion in leaves of $\mathrm{C}_{3}, \mathrm{C}_{4}$, and $\mathrm{C}_{3} / \mathrm{C}_{4}$ intermediate Panicum species. Crop Science, v.23, n.1, p.147-155, 1983.

ARGILLIER, O; MÉCHIN, V.; BARRIÈRE, Y. Inbred line evaluation and breeding for digestibility-related traits in forage maize. Crop Science, v.40, n.6, p.1596-1600, 2000.

BARNEVELD, S.L. van. Chemical and physical characteristics of grains related to variability in energy and amino acid availability in ruminants: a review. Australian Journal of Agricultural Research, v.50, n.5, p.667-687, 1999.

BARRY, T.N.; DUNCAN, S.J. The role of condensed tannins in the nutritional value of Lotus pedunculatus 1 . Voluntary intake. British Journal of Nutrition, v.51, n.3, p.485-491, 1984.

BARRY, T.N.; MANLEY, T.R. The role of condensed tannins in the nutritional value of Lotus pedunculatus for sheep 1. Quantitative digestion of carbohydrate and protein. British Journal of Nutrition, v.51, n.3, p.493-504, 1984.

BEEVER, D.E.; GILL, M.; SUTTON, J.D. Limits to animal production with high forage diets. Journal of Animal Science, v.67 (Suppl.1):298 (Abstr.), 1989.

BERLYN, G.P.; MIKSCHE, J.P. Botanical microtechnique and cytochemistry. Ames: Iowz State Univerty, 1976. 276p.

BERNAYS, E.A.; DRIVER, G.C.C; BILGENER, M. Herbivores and plant tannins. Advances in Ecological Research, v.19, p.263-302, 1989.

BLACK, C.C. Ecological implications of dividing plants into groups with distinct photosynthetic production capacities. Advances Ecology Research, v.7, n.1, p.87-114, 1971.

BRISKE, D.D. Strategies of plant survival in grazed systems: A functional interpretation. In: HODGSON, J. \& ILLIUS, A.W. (Eds.). The ecology and management of grazing systems. Wallingford: CAB INTERNATIONAL, 1996. p. 3767.

CASLER, M.D.; VOGEL, K.P. Accomplishments and impact from breeding for increased forage nutritional value. Crop Science, v.39, n.1, p.12-20, 1999.

CHESSELET, P.; WOLFSON, M.M.; ELLIS, R.P. A comparative histochemical study of plant polyphenols in southern African grasses. Journal of Grassland Society of South African, v.9, n.3, p.119-125, 1992.

CONE, J.W.; CLINÉ-THEIL, W.; MALESTEIN, A. et al. Degradation of starch by incubation with rumen fluid. A comparison of differente starch sources. Journal of the Science of Food and Agriculture, v.49, n.2, p.173-183, 2006.

CRAIG, W.M.; BRODERICK, G.A.; RICKER, D.B. Quantification of microorganisms associated with the particulate phase of ruminal ingesta. Journal of Nutrition, v.117, n.1, p.56-64, 1987. 
DAYKIN, M.E.; HUSSEY, R.S. Staining and histopathological techniques in nematology. In: BACKER, K.R.; CARTER, C.C.; SASSER, J.N. (Eds.) An advance treatise on Meloidogyne. Releigh: North Caroline State University Graphics, 1985. p.39-48.

DREHER, M.L.; DREHER, C.J.; BERRY, J.W. Starch digestibility of foods: A nutritional perspective. Critical Reviews in Food Science and Nutrition, v.37, n.1, p.47-53.

ELLIS, R.P. Tannin-like substances in grass leaves. Memoirs of the Botanical of South Africa, n.59, 1990, 80p.

ENGELS, F.M.; JUNG, H.G. Alfafa stem tissues: cell-wall development and lignification. Annals of Botany, v.82, n.5, p.561-568, 1998

EVERS, A.D.; BLAKENEY, A.B.; O’BRIEN, L. Cereal structure and composition. Australian Journal Agricultural Research, v.50, n.5, p.629-650, 1999.

FLORES, J.A.; MOORE, J.E.; SOLLENBERGER, L.E. Determinants of forage quality in Pensacola bahiagrass and Mott elephantgrass. Journal of Animal Science, v.71, n.8, p.1606-1614, 1993.

GAHAN, P.B. Plant histochemistry and cytochemistry. Academic Press, London, 1984. 301p.

GALYEAN, M.L.; GOETSCH, A.L. Utilization of forage fiber by ruminants. In: JUNG, H.D.; BUXTON, D.R.; HATFIELD, R.D. et al. (Eds.). Forage cell wall structure and digestibility. ASA-CSSA-SSSA, Madison, 1993. p.33-71.

GARCÍA-LARA, S.; BERGVINSON, D.J.; BURT, A.J. et al. The role of pericarp cell wall components in maize weevil resistance. Crop Science, v.44, n.5, p.1546-1552, 2004.

GRABBER, J.H; JUNG, G.A. Isolation of parenchyma and sclerenchyma cell types from the plant parts of grasses. Crop Science, v.31, n.3, 838-844, 1991.

GUO, D.; CHEN, F.; WHEELER, J. et al. Improved of in-rumen digestibility of alfafa forage by genetic manipulation of lignin O-methytransferases. Transgenic Research, v.10, n.5, p.457464, 2001.

HAGQUIST, C.W. Preparation and care of microscope slides. American Biology Teacher, v.36, n.4, p.414-417, 1974.

HANNA, W.W.; MONSON, W.G.; BURTON, G.W. Histological examination of fresh leaves after in vitro digestion. Crop Science, v.13, n.1, p.98-102, 1973.

HARBERS, L.H.; BRAZLE. F.K.; RAINTEN, D.J. et al. Microbial degradation of smooth brome and tall fescue observed by scanning electron microscopy. Journal of Animal Science, v.51, n.1, p.439-446, 1981.

HARBORNE, J.B. General procedures and measurement of total phenolics. In: DEY, P.M.; HARBORNE, J.B. (Eds.). Methods in plant biochemistry. Plant phenolics. Academic Press, London, 1989. p.1-28.

HIGUCHI, T. Lignin biochemistry: Biosynthesis and biodegradation. Wood Science Technology, v.24, n.1, p.2363, 1990.

HUNTINGTON, G.B. Starch utilization by ruminants: from basis to the bunk. Journal of Animal Science, v.75, n.3, p.852-867, 1997.

JENKS, M.A.; JOLY, R.J.; PETERS, P.J. et al. Chemically induced cuticle mutation affecting epidermal conductance to water vapor and disease susceptibility in sorghum bicolor (L.) Moech. Plant Physiology, v.105, n.4, p.1239-1245, 1994.

JENSEN, W.A. Botanical histochemistry. Freeman and Co., San Francisco, 1962. 408p.

JOHANSEN, D.A. Plant microtechnique. McGraw-Hill, New York, 1940. 523p.

JONES, G.A.; McALLISTER, T.A.; MUIR, A.D. et al. Effects of sainfoin (Onobrychis viciifolia Scop.) condensed tannins on growth and proteolysis by four strains on ruminal bacteria. Applied and Environmental Microbiology, v.60, n.4, 13741378, 1994.

JUNG, H.G.; BUXTON, D.R. Forage quality variation among maize inbreds: Relationships of cell-wall composition and in-vitro digestibility for stem internodes. Journal of the Science of Food Agriculture, v.66, n.3, p.313-322, 1994.

JUNG, H.G.; CASLER, M.D. Maize stem tissues: Cell wall concentration and composition during development. Crop Science, v.46, n.4, p.1793-1800, 2006a.

JUNG, H.G.; CASLER, M.D. Maize stem tissues: Impact of development on cell wall degradability. Crop Science, v.46, n.4, p.1801-1809, 2006b.

JUNG, H.G.; DEETZ, D.A. Cell wall lignification and degradability. In: JUNG, H.G.; BUXTON, D.R.; HATFIELD, R.D. et al. (Eds.). Forage cell wall structure and digestibility. Madison: ASA-CSSA-SSSA, 1993. p.315-346.

JUNG, H.G.; ENGELS, F.M. Alfafa stem tissues: cell wall deposition, composition, and degradability. Crop Science, v.42, n.2, p.524-534, 2002.

JUNG, H.G.; LAMB, J.F.S. Stem morphological and cell wall traits associated with divergent in vitro neutral detergent fiber digestibility in Alfalfa clones. Crop Science, v.46, n.5, p.2054-2061, 2006.

JUNG, H.G.; MORRISON, T.A.; BUXTON, D.R. Degradability of cell-wall polysaccharides in maize internodes during stalk development. Crop Science, v.38, n.4, p.1047-1051, 1998.

JUNG, H.G.; SHEAFFER, C.C. Influence of Bt transgenes on cell wall lignification and digestibility of maize stover for silage. Crop Science, v.44, n.5, p.1781-1789, 2004.

KOTARSKI, S.F.; WANISKA, R.D.; THURN, K.K. Starch hydrolysis by the ruminal microflora. Journal of Nutrition, v.122, n.1, p.178-190, 1992.

KRAUSE, D.O.; STUART, E.D.; MACKIE, R.I. et al. Opportunities to improve fiber degradation in the rumen: microbiology, ecology, and genomics. Microbiology Reviews, v.27, n.5, p.663-693, 2003.

LEMPP, B. Avaliações qualitativas, químicas, biológicas e anatômicas de lâminas de Panicum maximum Jacq. cv. Aruana e Vencedor. Tese (Doutorado em Zootecnia) Faculdade de Ciências Agrárias e Veterinárias, Universidade Estadual Paulista, Jaboticabal. 148p., 1997.

LEMPP, B.; VALLE, C.B. do; MORAIS, M.G. da et al. Physical impediment towards digestive breakdown in leaf blades of Brachiaria brizantha. In: INTERNATIONAL GRASSLAND CONGRESS, XX., 2005, Dublin. Proceedings... Dublin: Grassland Society, 2005. p.102.

MAcADAN, J.W.; MAYLAND, F. The relationship of leaf strength to cattle preference in tall fescue cultivars. Agronomy Journal, v.95, n.2, p.414-419, 2003.

MACE, ME.; HOWELL, C.R. Histochemistry and identification of condensed tannin precursors in roots of cotton seedlings. Canadian Journal of Botany, v.52, n.10, p.2423-2426, 1974.

MAGAI, M.M; SLEPER, D.A.; BEUSELINCK, P.R. Degradation of three war-season grasses in a prepared cellulase solution. Agronomy Journal, v.86, n.6, p.10491053, 1994.

MARTINS, A.S. Enzimas fibrolíticas exógenas na alimentação de bovinos. Tese (Doutorado em Zootecnia) Faculdade de Ciências Agrárias e Veterinárias, Universidade Estadual Paulista, Jaboticabal. 148p., 2003.

MAUSETH, J.D. Plant Anatomy. The Benjamin/Cummings Publishing Company. Inc. California.1988. 560p.

McALLISTER, T.A.; BAE, H.D.; JONES, G.A. et al. Microbial attachment and feed digestion in the rumen. Journal of Animal Science, v.72, n.11, p.3004-3018, 1994.

McAllister, T.A.; CHENG, K.J.; RODE, L.M. et al. Digestion of barley, maize, and wheat by selected species of ruminal bacteria. Applied and Environmental Microbiology, v.56, n.10, p.3146-3153, 1990.

McALLISTER, T.A.; PHILLIPPE, R.C.; RODE, L.M. et al. Effect of the protein matrix on the digestion of cereal grains by ruminal microorganisms. Journal of Animal Science, v.71, n.1, p.205-212, 1993.

MÉCHIN, V.; ARGILLIER, O.; HÉBERT, Y. et al. Genetic

๑ 2007 Sociedade Brasileira de Zootecnia 
analysis and QTL mapping of cell wall digestibility and lignification in silage maize. Crop Science, v.41, n.3, p.690697, 2001.

MEIRELLES, P.R. de L.; BATISTA, L.A.R.; SOUZA, G.B. de Quantificação e distribuição de taninos em gramíneas forrageiras tropicais. In: REUNIÃO ANUAL DA SOCIEDADE BRASILEIRA DE ZOOTECNIA, 42., 2005, Goiânia. Anais... Goiânia: Sociedade Brasileira de Zootecnia/Gmosis, [2005] 17par. CD-ROM. Forragicultura. FOR-561

MIRON, J.; YOKOYAMA, M.; LAMED, R. Bacterial cell surface structures involved in lucerne cell wall degradation by pure culture of cellulolytic rumen bacteria. Applied Microbiology and Biotechnology, v.32, n.2, p.218-222, 1989.

MIRON, J.; BEM-GHEDALIA, D. Untreated and delignified cotton stalks as model substrates for degradation and utilization of cell wall monosaccharides components by defined ruminal cellulolytic bacteria. Bioresource Technology, v.43, n.3, p.756-759, 1993.

MIRON, J.; BEN-GHEDALIA, D. The degradation and utilization of wheat-straw cell-wall monosaccharide components by defined ruminal cellulolytic bacteria. Applied Microbiology and Biotechnology, v.38, n.3, p.432-437, 1992.

MIRON, J.; BEN-GHEDALIA, D.; MORRISON, M. Invited review: Adhesion mechanisms of rumen cellulolytic bacteria. Journal of Dairy Science, v.74, n.7, p.1294-1309, 2001.

MORRISON, T.A.; JUNG, H.G.; BUXTON, D.R. et al. Cellwall composition of maize internodes of varying maturity. Crop Science, v.38, n.4, p.455-460, 1998.

NAKANO, J.; MESHITSUKA, G. The detection of lignin. In LIN, SY.; DENCE, C.W. (Eds.). Methods in lignin chemistry. Springer Verlag, Berlin, 1992. p.23-32.

NORTON, B.W. The significance of tannins in tropical animal production. In: BROOKER, J.D. (Ed.). Tannins in livestock and human nutrition. Aciar Books on Line, 2000. p.14-23.

OWENS, F.N.; SECRIST, D.S.; HILL, W.J. et al. The effect of grain source and grain processing on performance of feedlot cattle: A Review. Journal of Animal Science, v.75, n.3, p.868-879, 1997.

PACIULLO, D.S.; GOMIDE, J.A.; SILVA, E.D.A.M. et al. Degradação in vitro de tecidos da lâmina foliar e do colmo de gramíneas forrageiras tropicais, em função do estádio de desenvolvimento. Revista Brasileira de Zootecnia, v.31, n.2, p.900-907, 2002.

PHILIPPEAU, C.; MICHALET-DOREAU, B. Influence of genotype and stage of maturity of maize on rate of ruminal starch degradation. Animal Feed Science and Technology, v.68, n.1-2, p.25-35, 1997.

PHILIPPEAU, C.; MONREDON, F.D.; MICHALETDOREAU, B. Relationship between ruminal starch degradation and the physical characteristics of corn grain. Journal of Animal Science, v.77, n.1, p.238-243, 1999.

PRYCHID, C.J.; RUDALL, P.J.; GREGORY, M. Systematics and biology of silica bodies in monocotyledons. The Botanical Review, v.69, n.3, p.377-440, 2003.

RALPH, J.; HATFIELD, R.D.; PIQUEMAL, J. et al. NMR characterization of altered lignins extracted from tabacco plants down regulated for lignification enzymes cinnamylacohol dehydrogenase and cinnamoly-CoA redutase. Biochemistry, v.95, n.22, p.12803-12808, 1998.

REED, J.D. Nutritional toxicology of tannins and related polyphenols in forage legumes. Journal of Animal Science v.73, n.5, p.1516-1528, 1995.

ROONEY, L.W.; PFLUGFELDER, R.L. Factors affecting starch digestibility with special emphasis on sorghum and corn Journal of Animal Science, v.63, n.5, p.1607-1623, 1986.

SCALBERT, A. Antimicrobial properties of tannins Ptytochemistry, v.30, n.12, p.3875-3883, 1991.
SPICER, L.A.; THEURER, C.B.; SOWE, J. et al. Ruminal and post-ruminal utilization of nitrogen and starch from sorghum grain, corn and barley-based diets by beef steers. Journal of Animal Science, v. 62, n.3, p.521-530, 1986.

SREBOTNIK, E.; MESSNER, K. A simple method that uses defferential stainning and light microscopy to assess the selectivity of wood delignification by white rot fungi. Applied and Environmental Microbiology, v.60, n.4, p.1383-1386, 1994.

TAYLOR, C.C.; ALLEN, M.S. Corn grain endosperm type and brown midrib 3 corn silage: site of digestion and ruminal digestion kinetics in lactating cows. Journal of Dairy Science, v. 88, n.4, p.1413-1424, 2005.

TEATHER, R.M.; HEFFORD, M.A.; FORSTER, R.J. Genetics of rumen bacteria. In: HOBSON, P.N.; STEWART, C.S. (Eds.). The rumen microbial ecosystem. Blackie, Merborne, 1997. p.427-466.

TECLE, I.Y.; VIANDS, D.R.; HANSEN, J.L. et al. Response from selection for pectin concentration and indirect response in digestibility of Alfalfa. Crop Science, v.46, n.3, p.10811087, 2006.

TERASHIMA, N.; FUKUSHIMA, K.; HE, L.F. et al. Comprehensive model of lignified plant cell wall. In: JUNG, H.G.; BUXTON, D.R.; HATFIELD, R.D. et al. (Eds.). Forage cell wall structure and digestibility. Madison: ASA-CSSASSSA, 1993. p.247-270

THEODOROU, M.K.; BARAHONA, R.; KINGSTONSMITH, A. New perspectives on the degradation of plant biomass in the rumen in the absence and presence of condensed tannins. In: BROOKER, J.D. (Ed.). Tannins in livestock and human nutrition. Aciar Books on Line, 2000. p.44-50.

THEUNISSEN, J.D. An improved method for studying grass leaf epidermis. Stain Techonology, v.64, n.5, p.239-242, 1989.

TORRES, F.E. Avaliação de produção e valor nutricional de ecotipos de Brachiaria brizantha. Dissertação (Mestrado em Agronomia) - Universidade Federal de Mato Grosso do Sul, Dourados. 56p., 2002.

VINCENT, J.F.V. Strength and fracture of grasses. Journal of Materials Science, v.26, n.6, p.1947-1950, 1991.

WANG, J.K.; LIU, J.X.; LI, J.Y. et al. Histological and rumen degradation changes of rice straw stem epidermis as influenced by chemical pretreatment. Animal Feed Science and Techonology (2006). Doi: 10.1016/j.anifeedsci. 2006.08.017.

WILSON, J.R. Organization of forage plant tissues. In: JUNG, H.G., BUXTON, D.R. HATFIELD, R.D. et al. (Eds.). Forage cell wall structure and digestibility. Madison: ASA-CSSASSSA, 1993. p.1-27.

WILSON, J.R.; AKIN, D.E.; McLEOD, M.N. et al. Particle size of leaves of a tropical and temperate grass by cattle. II. Relation of anatomical structure to the process of leaf breakdown through chewing and digestion. Grass and Forage Science, v.44, n.1, p.65-75, 1989.

WILSON, J.R.; BROWN, R.H.; WINDHAM, W.R. Influence of leaf anatomy on the dry matter digestibility of $\mathrm{C}_{3}, \mathrm{C}_{4}$, and $\mathrm{C}_{3} / \mathrm{C}_{4}$ intermediate types of Panicum species. Crop Science, v.23, n.1, p.142-146, 1983.

WILSON, J.R.; HATTERSLEY, P.W. In vitro digestion of bundle sheath cells in rumen fluid and its relation to the suberized lamella and $\mathrm{C}_{4}$ photosynthetic type in Panicum species. Grass and Forage Science, v.38, n.1, p.219-223, 1983. 